\title{
Urgentní stavy v neurologii
}

\section{MUDr. Petr Hon - editor hlavního tématu Neurologická klinika FN Ostrava}

Před deseti lety na tomto místě, na stránkách Neurologie pro praxi, ve svém úvodu k tématu „neurointenzivní péče" popsal primář Kalina krátkou historii a bouřlivý rozvoj neurointenzivní péče. Nelze, než s ním naprosto souhlasit, že i v roce 2017 jde v neurointenzivní péči v první raadě o neurologii (Kalina, 2007). Vybaven znalostmi z anatomie, patofyziologie nervového systému, dovednostmi a schopností interpretace elektrofyziologických a cerebrovaskulárních diagnostických metod, vyráží neurointenzivista do boje s tak závažnými stavy, jakými urgentní neurologická onemocnění jsou. Základ v obecném intenzivistickém vzdělání je nezbytou součástí „bojové výbavy”.

Stavy spojené s poruchou vědomí se stávají ve chvili, kdy k nim dojde, dramaty pro všechny zúčastněné. Rychlost, s jakou dokáže ošetřující lékař na místě príhody správně zareagovat jak ve smyslu základního zajištění vitálních funkcí, tak z hlediska potřebné další diagnostiky dle výsledků cílené terapie, je významným faktorem pro další osud pacienta.

Jednou z príčcin akutní poruchy vědomí, která se stává bezprostředním ohrožením pro

\section{LITERATURA}

1. Kalina M. Neurointenzivní péče. Neurol. praxi, 2007; 1: 9. život nemocného, je status epilepticus. I zde platí pravidlo rychlé diagnostiky a cílené terapie, směřující k ukončení záchvatové aktivity. Nová klasifikace a doporučení základního léčebného algoritmu, včetně časové osy př́slušných kroků, potřebných ke zvládnutí konvulzivního i nekonvulzivního epileptického statu, jsou opěrnými body v terapii život ohrožujícího stavu, jakým nepochybně status epilepticus je.

V terapii cévních mozkových príhod došlo v posledních letech k významnému posunu a zkvalitnění léčby ischemických iktů. Léčebné možnosti hemoragických mozkových príhod jsou ve své podstatě omezeny převážně na terapii následků mozkového inzultu, či prevence sekundárního mozku. Znalosti zahrnující korekci koagulopatií, dekompenzované hypertenze a současně správně nastavená antiedematózní opatření, spolupráce s neurochirurgy, invazivními angiology, schopnost poskytnout priměřenou podporu selhávajícím vitálním funkcím pacienta, tím vším musí být vybaven neurointenzivista $v$ péči o pacienty s hemoragickou cévní mozkovou príhodou. I přes určitou skepsi lze tak zvýšit naději na možnost přežití hemoragického iktu při zachování co nejlepší kvality života.

Onemocnění periferních nervů a svalů jsou ve skupině urgentních stavů souvisejících s postižením nervového systému v menšině. Nižší výskyt a s ním související i menší zkušenost s terapií, může být limitem pro lékaře poskytujícího péči pacientům s akutní polyradikuloneuritidou, s její nejzávažnější variantou, postihující respirační svaly, autonomní nervový systém a vedoucí tak k život ohrožujícímu stavu. Praktické zkušenosti s léčbou těžkých forem Guillain-Barré syndromu mohou být pomocníkem v léčbě akutní polyradikuloneuritidy a jejích komplikací.

Problematika urgentních stavů souvisejících s neurologickými onemocněními je jistě širší, než zachycují následující souhrnné práce, její obsah naplňují stovky stránek knižních publikací věnující se neurointenzivní péči. Smyslem a cílem následujících článků je krom poskytnutí praktických zkušeností s danými urgentními stavy, též podtržením myšlenky primáře Kaliny: „neurointenzivní péče poskytovaná komplexně vzdělaným neurologem je pro akutně neurologicky nemocné velkým prínosem“ (Kalina, 2007) 